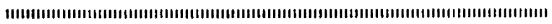

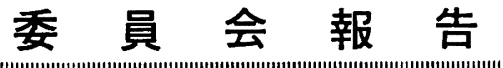

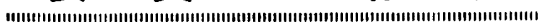

\title{
転炉酸素系統計装小委員会報告*
}

片田 中**

\section{Report of the BOF Oxygen-Line Instrumentation Sub-committee}

\author{
Tadashi KATADA
}

\section{1. まえがき}

本技術報告は，日本鉄鋼協会共同研究会計測部会に設 置された転师酸素系統計装小委員会における討議内容を まとめたものである.この小委員会は, 転炉設備をもつ 鉄龬 7 社の計装技術者が小委員となり，昭和 42 年 8 月 より 43 年 4 月まで 4 回の会合を開いて転炉酸素系統の 計装について広範な討議を行なつた。この間，酸素につ いての安全工学に関して横浜国立大学の北川徹三教授の 講議を受け, また計測器メーカーおよびバルブメーカー の技術者からも有益な意見を得ることができた。

本報告文では紙面の制限もあり実際の討議内容の多く の部分を割愛せざるを得なかつたまなた読者として計装 技術者以外の技術者を主に考えたので，必ずしも委員会 における討議内容にこだわらず, 計装機器の細かい仕様 や保守整備の面は簡略に記している.これら詳細につい ては参考交献にあげた「転师酸素系統計装小委員会竍告 書」を参照していただければ幸いである。

\section{2、酸素配管の安全性}

酸素系統の計装を考えるにあたつて, 第一に安全性を 考えるべきことは言うまでもない。過去, われわれは実 際に転炉酸素配管系統において，不幸な事故火災を幾度 か経験している。ここでは, 酸素配管上の安全性に対す る基本的な配虑について述べたい。なお，この章は小委 員会がとくに講師として依頼した横浜国立大学工学部北 川徹三教授の講演に基つくものである.

\section{$2 \cdot 1$ 酸素中における鉄の燃焼}

酸素配管事故を爆発事故と呼ぶことがあるが，これは 正確ではなく，あくまでも鉄などの配管素材の酸素中に おける燃焼である. 一般に, ある温度に保たれた酸素雾 囲気中に鉄粉を投入し，発火するまでの時間によつて瞬 間発火温度および最低発火温度を定義する.Fig. 1 は, 横軸に発火温度, 縦軸に鉄粉投入後発火するまでの待ち 時間の対数をとつて両者の関係を調べたものである.瞬 間発火温度は, 待ち時間 $1 \mathrm{sec}$ 以内で発火する温度, 最低 発火温度は，この温度以下では待ち時間をいくら延ばし
ても発火しない限界温度である.瞬間発火温度は鉄粉粒

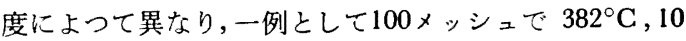
メッシュで $421^{\circ} \mathrm{C}, 10 \mathrm{~g}$ の鉄塊では $930^{\circ} \mathrm{C}$ となる。 た酸素が常圧から $30 \mathrm{~kg} / \mathrm{cm}^{2}$ の高圧になると, 発火温 度はさらに10 $100^{\circ} \mathrm{C}$ 低下する. 鉄塊は一度発火すると 鉄の燃焼熱は非常に大きい $(97 \cdot 6 \mathrm{kcal} / \mathrm{mol})$ ため, 急激 な温度上昇をもたらし燃焼が継続するが，消費される酸 素量も大きいので高濃度の酸素の供給を停止すれば大気 中で然焼を継続するこ・とはできない.

\section{2 酸素配管の発火機錐}

配管の発火原因としては，まず可燃物が配管の局所に 付着していることが考えられる。これにはつぎのような 場合が考えられる。

（1）酸素中に混入した油が，配管接手や弁などのデ ッドスペースに付着している場合

（2）配管の油分を除去するために用いた洗浄棛が配 管内部に残留している場合

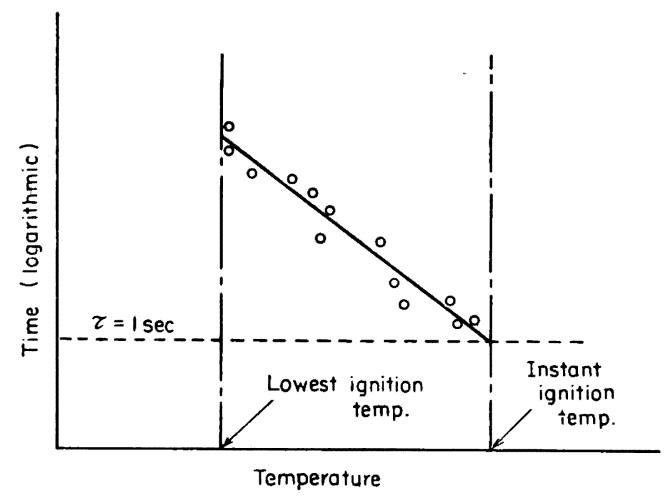

Fig. 1. Relation between the ignition and the time after the iron powder is put into oxygen atmosphere.

* 昭和 43 年 9 月本会講演大会にて発表 昭和 45 年 7 月 18 日受付

** 新日本製鉄 (株) 計測部会転炉酸素系統計装小委員会 主查 
（3）可燃性のガスケット材料が使われた場合

潤滑油やゴムの最低発火温度 は常圧酸素中で $300^{\circ} \mathrm{C}$ 前後であり，また不燃性と言われるテフロンでも $500^{\circ} \mathrm{C}$ であつて, 高圧酸素中ではこれより $100^{\circ} \mathrm{C}$ 近く低下す ると考えられる。

一方，配管中には管壁から発生したスケールや鉄粉が 存在し，これらは酸素気流に運ばれる間に管壁との摩擦 で発熱発火する.この赤熱粒子が前述の可燃物に付着す ると可燃物が発火し，ついには配管素材の燃焼が始まる ことが考えられる. また配管のT字部分などでは赤熱粒 子が内壁に次々に衝突して管壁に穴をあけ発火を起こさ せることも考えられる. 以上のことはこれまでの酸素事 故が配管の T字部や弁部などで多く発生していることか らもうなずける・また湿り酸素を通した後に乾き酸素を 通すと事故が起きやすいといわれているが，これもスケ 一ルが発生しやすくなるということで説明される.

\section{$2 \cdot 3$ 酸素事故防止対策}

前述の観点から酸素事故防止対策を列記するとつぎの ようになる。

（1）配管内をできるだけ平滑にし，デッドスペース や急激な方向転換部を作らぬこと・

（2）ガスケット，パッキングなどの配管材料に可燃 物の使用を避けること.

（3）配管内の油脂分を洗浄剤でとり除くこと.また 洗浄剤は不燃性のものを選び,管内に残留させないこと.

（4）配管内のスケールなど固形粒子をとり除き，ま た酸素プラントなどから混入しないように注意する.

（5）弁類の急激な開閉は断熱圧縮による温度上昇を 招くおそれがあるので避ける。

（6）配管の一部に銅管を入れることにより，銅管部 分からの発火を防止できる.（銅の燃焼熱は小さいので 燃焼は継続しにくい)

管内の酸素輸送流速については, 従来 $8 \mathrm{~m} / \mathrm{sec}$ 以下 $(30$ 気圧）という基準があつたが，上述の対策を施せば必ず しもこれ以下に抑える必要はないと思われる. 西独では 1967 年以降 $40 \mathrm{~kg} / \mathrm{cm}^{2}$ 以下で $25 \mathrm{~m} / \mathrm{sec}$ 以下として いる。

\section{3. 酸素流量の測定精度}

\section{1 吹鍊制御上必要とされる精度}

酸素流量を測定するのはいうまでもなく吹鍊作業を行 なうためであるから，その精度は吹鍊を適中させるとい う条件から决定されるべきものである，吹鍊制御では， 銅浴の温度および成分を適中させなければならない。ま ず温度の点から考えてみると

\section{溶鋼重量}

終点までの所要酸素量

酸素流量測定誤差

酸素流量測定精度
溶鋼 $\mathbf{t}$ 当たりの酸素による鋼浴準度上昇率

終点温度誤差 $\tau\left({ }^{\circ} \mathrm{C} / \mathrm{Nm}^{3} / \mathrm{t}\right)$ $\Delta \theta\left({ }^{\circ} \mathrm{C}\right)$

とすると

$$
\begin{aligned}
& \Delta \theta=\frac{\tau \cdot \Delta F}{W} \\
& \alpha=\frac{100 \Delta F}{F}=\frac{100 \Delta \theta W}{\tau F}
\end{aligned}
$$

一例として $W=100 \mathrm{t}, F=5000 \mathrm{Nm}^{3}, \tau=10^{\circ} \mathrm{C} / \mathrm{Nm}^{3}$ $/ \mathrm{t}$ として, 許容誤差を $|\Delta \theta| \leq 10^{\circ} \mathrm{C}$ とすると, 前式 より所要精度は $|\alpha|<2(\%)$

この場合は終点温度誤差として酸素流量測定誤差のみ を考えたが，実際は装入物の条件や反応上の誤差要因が 大きいので，流量測定精度はもつと小さくなければなら ない，仮りに許容誤差全体の $20 \%$ と定めれば

$$
|\alpha|<2 \times 0.2=0.4(\%)
$$

もちろん, これらの数值は各転炉工場の操業条件や鋼種 によつて違つてくる.

つぎに成分に関しても，上記の考え方と同じように所 要精度を計算できる。ただし，酸素による脱炭効率は， カーボンの成分範囲によつて異なりまた終点のカーボン 許容誤差も成分範囲によつて異なるので，成分範囲別に 調べる必要がある. 所要測定精度の計算例を Table 1 に示す.

さて, 以上の例で算出したような精度を絶対精度とし て得ることは現状の計器の精度からは困難で, 実際には $1 \%$ 近い誤差が生じていると考えられる。しかしながら 操業上は絶対精度として偏り誤差があつても再現性精度 として高い精度が得られれば吹鍊作業上は支障ないので 以下に述べるような配虑を行なつて, 再現性精度を高め ることを考える必要がある。

\section{2 測定精度向上のための留意点}

流量測定はオリフィス式となるので，オリフィスに関 して下記の点に十分注意する必要がある.

（1）オリフィスが正確に設計どおりの寸法になつて いること，とくにエッジ形状が重要である．また配管に 対して偏心しないように正確な位置に取付けること.

（2）オリフィス前後に十分長い直管部分をとるこ と.

（3）配管全体からみてオリフィス部分での許容圧力

Table 1. The necessary accuracy of measuring oxygen flow for the determination of bath carbon.

\begin{tabular}{l|l|l|ll}
\hline \hline $\begin{array}{r}\text { Carbon } \\
\%\end{array}$ & $\begin{array}{l}\text { Decarbonizing } \\
\text { rate by oxygen }\end{array}$ & $\begin{array}{l}\text { Allowance } \\
\text { band of carbon }\end{array}$ & \multicolumn{2}{|c}{$\begin{array}{l}\text { Necersary } \\
\text { accuracy }\end{array}$} \\
\cline { 1 - 3 } $0.6 \%$ & $0.1 \% / \mathrm{Nm}^{3} / \mathrm{t}$ & $\pm 0.05 \%$ & $0.1 \mathrm{Nm}^{3} / \mathrm{t} 0.2 \%$ \\
0.2 & 0.04 & \pm 0.025 & 0.13 & 0.25 \\
0.15 & 0.03 & \pm 0.025 & 0.17 & 0.3 \\
0.10 & 0.02 & \pm 0.015 & 0.15 & 0.3 \\
0.05 & 0.01 & \pm 0.015 & 0.3 & 0.6 \\
\hline
\end{tabular}


損失を相当量確保し,オリフィス絞り比を十分とること.

（4）オリフィス上下流部の圧力変動をできるだけ減 らす.

（5）オリフィス前後の差圧の導圧管は，通酸開始時 に差圧変換器に片圧のかからぬように長さ，配管容量な どバランスを保つこと.

オリフィス部分での流体の温度および圧力が設計值よ り変化した場合には流量誤差となる．その影響の度合は 温度について $0.17 \% /{ }^{\circ} \mathrm{C}\left(20^{\circ} \mathrm{C}\right.$ 付近) 圧力については $3.2 \% / \mathrm{kg} / \mathrm{cm}^{2}\left(15 \mathrm{~kg} / \mathrm{cm}^{2}\right.$ 付近）となつており，とく に圧力は通酸量の変化に伴つて相当変わると考えられ, 死力, 温度による補正演算が必要である。

また，計器自体の誤差も当然考虑しなければならな い.オリフィス以降, 差圧変換器, 演算器, 指示計など 個々の計器単体の精度管理を行なうとともに, 全体とし ての組み合わせ誤差を最小にすることが重要である.

最近の転炉工場ではコンピューターコントロールがー 般的となつているので, 開平演算や圧力温度補正演算な どをアナログ計器で行なう代わりにコンピューター内部 で演算してしまうことも, 精度を高めるうえで非常に有 効である. また流量測定精度を長期的に維持するために は日常の計器の保守点検が重要である・酸素流量測定関 倸の計器については, 1 カ月に 1 回程度の総合チェック を行なうことが望ましい。ほとんどの製鉄所で，転炉酸 素系統の計器は保守対象として最重点管理計器の一つと
して取り扱われている。

\section{4. 転炉酸素系統計装モテル}

転炉酸素系統の計装は各製鉄所によつて操業方法や龬 種, 付帯条件, 設備上の制約などが異なり必ずしも 1 つ のモデルとしてまとめることはできない，そこでここで は代表的な計装モデルを 3 例 Fig. 2，3，4 に示しこれ らを比較しつつ計装上のポイントを明らかにしたい。な おここでは転炉 3 基の設備（2 基稼動， 1 基整備）につ いて示してあるが， 2 基の設 備でも考え方は同じであ る.

\section{1 配管と予備ライン}

従来の設備ではモデルのように，転炉基数より1本多 い4 系統の配管を持つ場合が少なくないが，最近の設備 では, 各機器の信頼性の向上に伴いモデル1のように転 炉基数と同じ 3 系統の配管を持つことが多くなつてい

る. 後者でも同時稼動が 2 基までならば， 1 系列は予備 ラインとして使えるので 2 系統同時に故障しない限り問 題ないわけである.

一方，モデル 2 では同じ炉に対して，配管系統を切換 えられない代わりに各系統で主要調節弁を 2 系路ずつ持 つている.この場合でも調節弁以外の故障を考えると故 障対策は完全とは言えない。

モデル1，3については各配管系統のうち，1 系列を 専用予備ラインとして使う方法と, 各采統を順次交替し

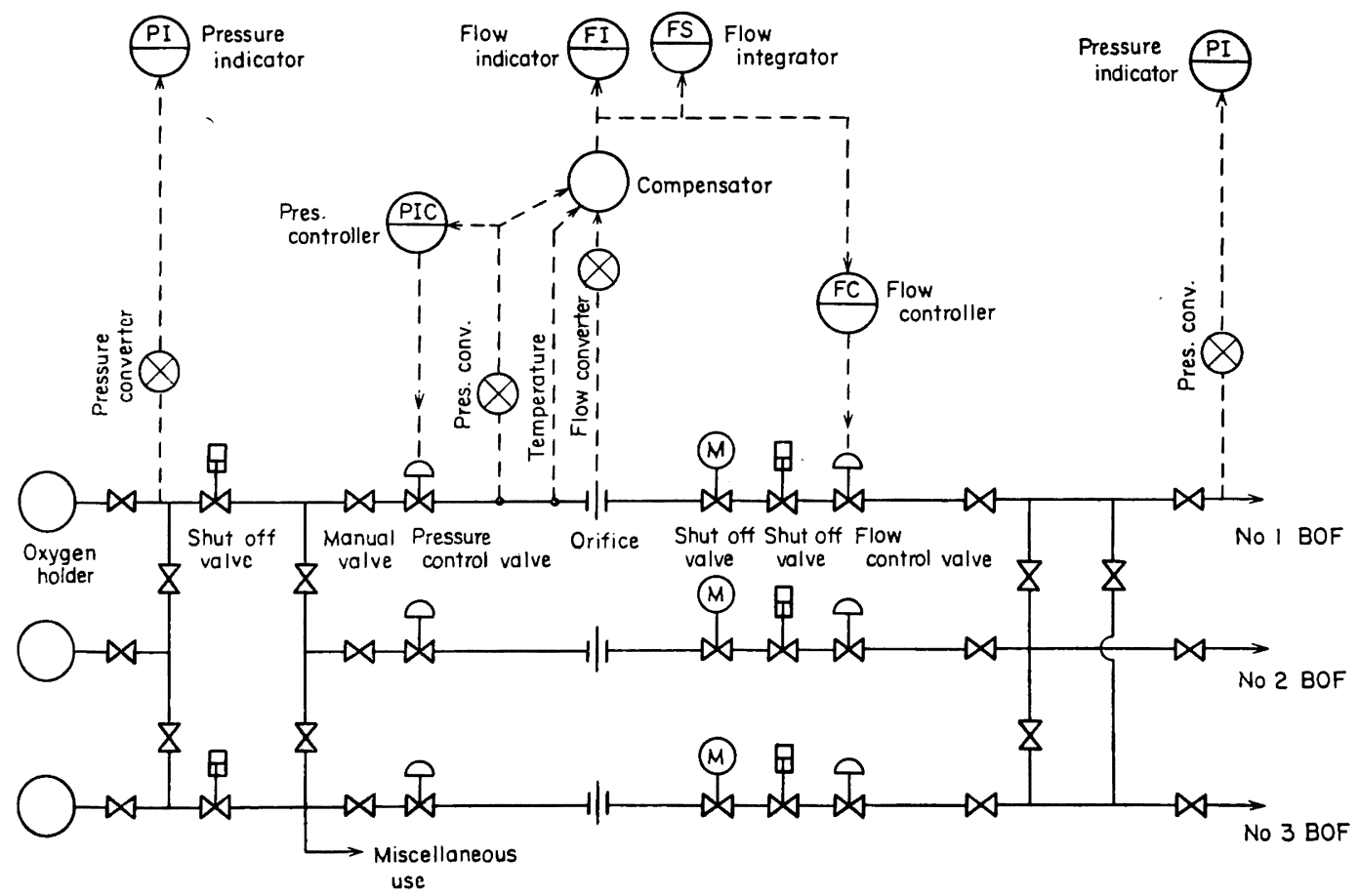

Fig. 2. Proposed instrumentation system No 1. 


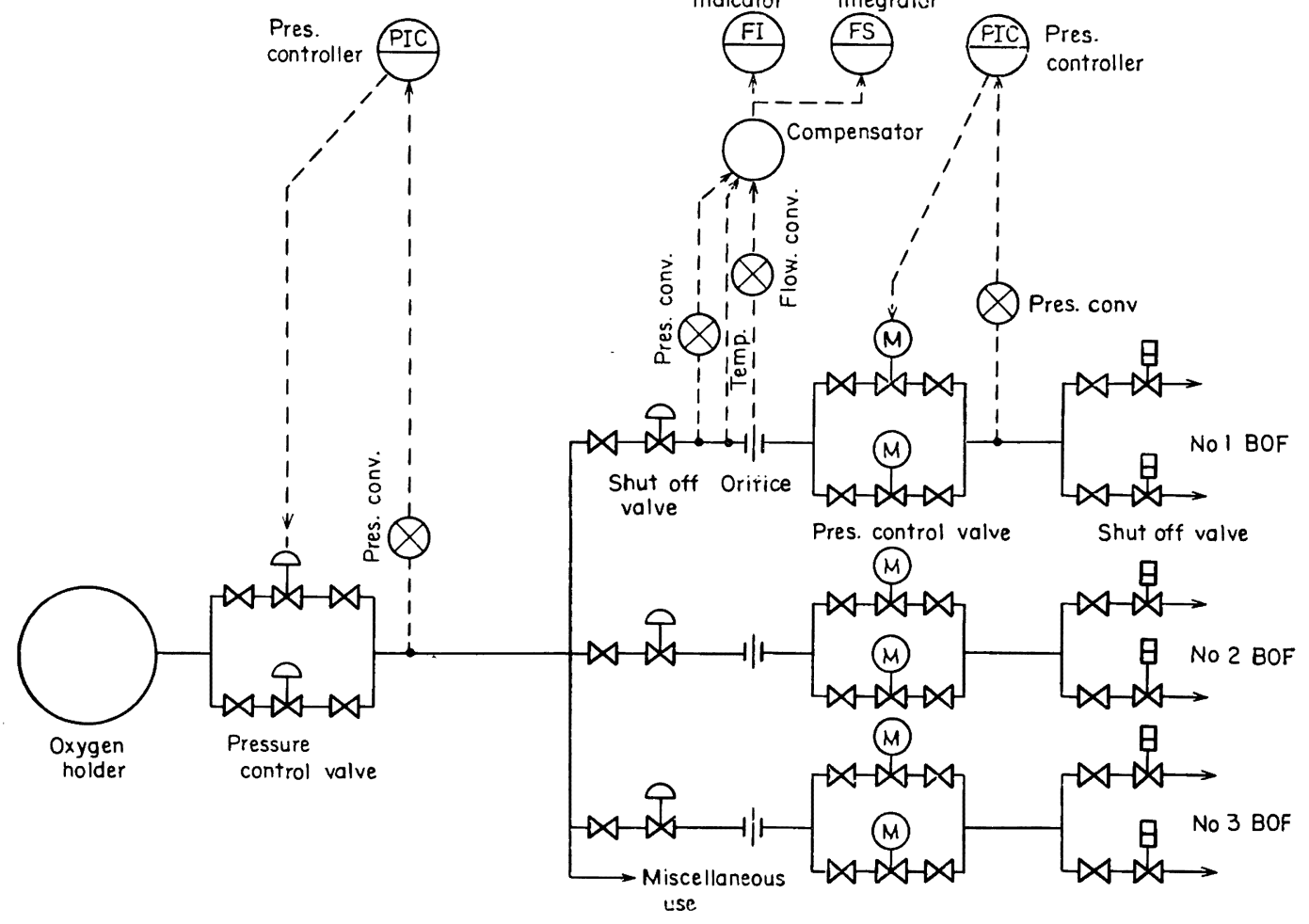

Fig. 3. Proposed instrumentation system No 2 .

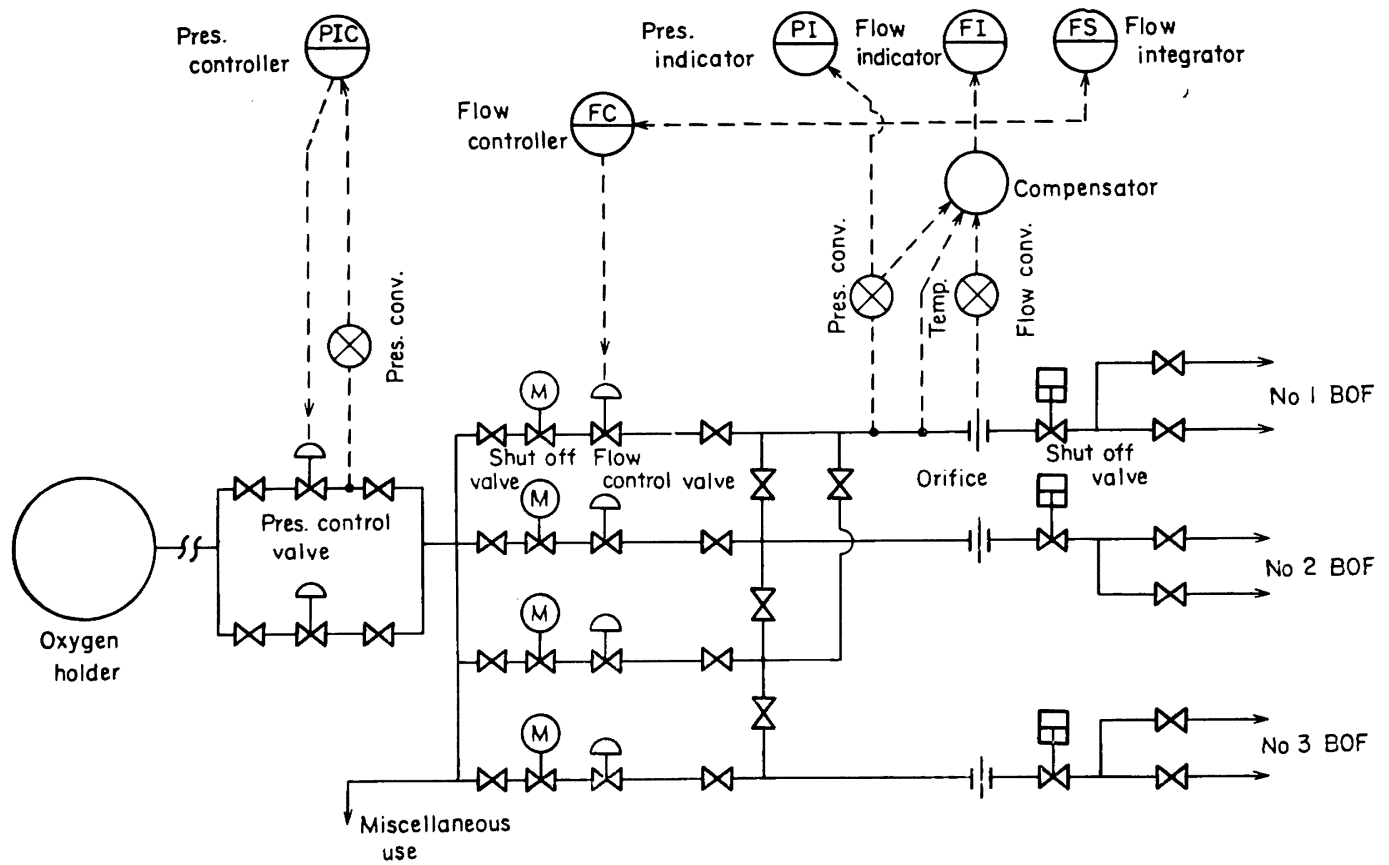

Fig. 4. Proposed instrumentation system No 3 . 
て使う方法がある．前者は配管系路が各炉に固定される ので流量測定上の偏りを生じないままた誤操作の心配も 少ない。しかし，専用予備ラインを長期間使用しない場 合は管内面のスケールの発生や弁作動の不良化などの問 題について，安全上の配虑が必要である.

\section{2 流量制御方式}

一般には, 酸素ホルダー出口または転炉工場内で一次 圧力制御を行ない，その後流量制御を行なうのが普通で ある.また，モデル 2 のように流量制御の代わりに圧力 制御を行なつて間接的に流量を制御するやり方もある.

モデル1は， 3 系統の各配管ラインごとに一次圧力制 御它行なつているのが特徵で, オリフィス上流側の圧力 が一定になるので流量測定上好ましい。そのかわりに， 圧力制御弁の数はモデル 2,3 より多くなる.またモデ ル1のような場合, 圧力制御弁と流量制御弁の間にある 程度の配管容量をとらないと制御の干涉を起こすことが あるので注意を要する.

オリフィスは, 通常流量調節弁（圧力制御方式では圧 力調節弁）の上流側に挿入するが，モデル 3 では流量調 節弁後に挿入している.これは流量測定の検出端である オリフィスおよび差圧変換器などと炉との組み合わせを 固定して, 配管系統を切換えてもその影響を受けないよ うにしようという考え方である.ただし流量の設定変更 を行なうとき, 上流側弁の動作が遅いとオリフィス上流 側生力が変動するため流量測定に悪影猳を与える.

\section{3 計萃機器仕栏}

計測器す仕样:つつては, 前章をでにある程度ふれて おり，亡た特殊なものもないので補足程度につきの事項
を上げておく

（1）酸素流量皘算值表示装置は, ディジタル表示が 見やすく, 最小表示単位は $2 \cdot 1$ の議論から原単位に換算 して $0 \cdot 1 〜 0.2 \mathrm{Nm}^{3} / \mathrm{t}$ になるようにする。

（2）酸素瞬時流量指示計の単位は, 従来 $\mathrm{Nm}^{3} / \mathrm{hr}$ を とつているが，操業上からは $\mathrm{Nm}^{3} / \min$ とするほうが 適当である.

（3）酸素流量制御系で，吹鍊を停止している間に流 量調節弁が全開になつてしまうことのないように適当な 開度でロックする必要がある.

(4) 差圧変換器などのベローズ内部のシール液には 不燃性のものを使う.

（5）計装工事には防爆対策を考虑する.

つぎに,バルブ類に関しては, 計装モデルに示されて いるように, 一次調節弁（圧力）二次調節弁（流量また は圧力）配管采統の切替遮断弁, 吹鍊用遮断弁, 危急遮 断弁および安全弁がある. 吹鍊用遮断弁は, チャージ゙ との吹鍊開始，終了時に開閉する弁を言い，モデル 1 の ように切替遮断弁で兼用する場合もあるが，モデル 2 ， 3 では切替遮断弁とは別に末端に装備している.このよ うに未端で開閉する方が吹鍊開始時の着火が早いと言わ れている.

上記の各種バルブについての仕様例を Table 2 に示 す.この表について以下補足しておく.

(1) 調節弁の駆動方式には，ダィヤフラム式以外に 電動式もあり，シークエンスに工夫を施す場合に便利で はあるが，開閉速度をあまり速くできない難点がある。

(2) 遮断弁については, モデル 3 のように空気圧と

Table 2. Specification of valves for oxygen line (an example).

\begin{tabular}{|c|c|c|c|c|c|}
\hline & $\begin{array}{l}\text { 1st control } \\
\text { valve }\end{array}$ & $\begin{array}{l}\text { 2nd control } \\
\text { valve }\end{array}$ & $\begin{array}{l}\text { Shut off valve } \\
\text { for emergency }\end{array}$ & $\begin{array}{l}\text { Shut off valve } \\
\text { for line exchange }\end{array}$ & $\begin{array}{l}\text { Shut off valve } \\
\text { for operation }\end{array}$ \\
\hline Actuator & Diaphragm (air) & Diaphragm (air) & Air cylinder & Electric motor & Air cylinder \\
\hline Port & Double ports & Double ports & Single port & Single port & Single port \\
\hline Meterial(body) & SCS 13 & SCS 13 & SCS 13 & SCS 13 & SCS 13 \\
\hline $\begin{array}{r}\text { Material (port } \\
\text { etc) }\end{array}$ & $\begin{array}{l}\text { SUS } 29 \\
\text { (stellite coated) }\end{array}$ & $\begin{array}{l}\text { SUS } 29 \\
\text { (stellite coated) }\end{array}$ & $\begin{array}{l}\text { SUS } 29 \\
\text { (stellite coated) }\end{array}$ & $\begin{array}{l}\text { SUS } 29 \\
\text { (stellite coated) }\end{array}$ & $\begin{array}{l}\text { SUS } 27 \\
\text { (stellite coated) }\end{array}$ \\
\hline Packing & Teflon & Teflon & Teflon & Teflon & Teflon \\
\hline $\begin{array}{l}\text { Pressure } \\
\text { durability }\end{array}$ & $\begin{array}{l}\text { Twice as strong } \\
\text { as hte upper } \\
\text { pressure }\end{array}$ & $\begin{array}{l}\text { Twice as strong } \\
\text { as the upper } \\
\text { pressure }\end{array}$ & $\begin{array}{l}\text { Twice as strong } \\
\text { as the upper } \\
\text { pressure }\end{array}$ & $\begin{array}{l}\text { Twice as strong as } \\
\text { the upper } \\
\text { pressure }\end{array}$ & $\begin{array}{l}\text { Twice as strong as } \\
\text { the upper pressure }\end{array}$ \\
\hline Leak & Less than $0.5 \%$ & Less than $0.5 \%$ & Less than $0.01 \%$ & Less than $0.01 \%$ & Less than $0.01 \%$ \\
\hline Operation & Air to open & Air to open & Air to open & $\longrightarrow$ & Air to open \\
\hline Time to open & Less than $15^{\mathrm{S}}$ & Less than $15 \mathrm{~S}$ & Less than $10^{\mathrm{s}}$ & Less than $30^{\mathrm{s}}$ & Less than $3^{s}$ \\
\hline Time to shut off & Less than $15 \mathrm{~s}$ & Less than $15 \mathrm{~S}$ & Less than $3^{s}$ & Less than $30^{\mathrm{s}}$ & Less than $3^{\mathrm{s}}$ \\
\hline
\end{tabular}


電動と二種類の駆動方式を併用し, 駆動源の故障に備え る考え方がある.

（3）弁本体材質にはＢＣを使用している例がある が, 強度的に SCS に劣るため本体が比較的大きくなる ので弁サイズには限界がある。

（4）調節弁の内弁や弁座は SUS 27 にステライト 溶着を施すが，メーカーによつてその範囲や深さが異な るので十分検討を要する.

（5）弁耐圧に対する考え方は二通りあつて，一つは 一次圧力調節弁の上流側圧力を基準とする考え方, 他は 下流側圧力を基準とする考え方である. 前者の場合は, 一次圧力調節弁の下流の配管および弁はすべて一次調節 弁と同等の耐圧が必要となり高価になるが，一次調節弁 のリークはあまり問題にならない. 後者では, 下流側の 弁類の耐圧を下げられるが, 一次調節弁のリークについ て制限を受け，安全弁の設置が必ず必要である.

\section{5. ๘とがき}

転炉酸素采統計装小委員会が, 昭和 43 年 4 月に最後の 会合を開いて解散して後, すでに 2 年が経過している. この間の状況の変化は, 転炉設備の大型化とコンピュー ター利用の増大であろう・これに伴い酸素系統の計装設
備の重要性はますます高まつているが，基本的な考え方 と問題点についてはとくに変つたことはなく, 本報告書 でふれた内容は現在でも十分役に立つと思う。

$$
\text { 文献 }
$$

1）転炉酸素系統計装小委員会報告書: 第41回日本鉄 龬協会共同研究会計測部会資料

2）高圧酸素ガス配管の燃焼事故とその原因: 北川ほ か「安全工学」5(1966) 4, p. 269～274

付: 転炉酸素系統計装小委員会名簿

\begin{tabular}{|c|c|c|c|c|c|}
\hline \multirow{3}{*}{$\begin{array}{ll}\text { 主 } & \text { 査 } \\
\text { 委 } & \text { 員 }\end{array}$} & 片田 & 中 & 富士製鉄 & 本 & 社 \\
\hline & \multicolumn{2}{|c|}{ 内藤功一郎 } & 八幡製鉄 & \multicolumn{2}{|c|}{ 八幡 /君津 } \\
\hline & 高橋 & 勝 & 富士製鉄 & 室 & \\
\hline & \multicolumn{3}{|c|}{ （第 1 回のみ出席） } & & \\
\hline " & 長尾 & 誠之 & 富士製鉄 & 室 & \\
\hline " & 堂脇 & 光郎 & 日本鋼管 & 京 & \\
\hline " & 羽田 & 守幸 & 川崎製鉄 & 千 & \\
\hline " & 高松 & 精一 & 住友金属 & 本 & \\
\hline " & 林 & 正照 & 神戸製龬 & 尼 & \\
\hline " & 金 & 尚俊 & 大阪製鋼 & 西 & \\
\hline 事 & 萩原 & 良衛 & 富士製鉄 & 本 & \\
\hline
\end{tabular}

